\title{
The absence of HPV DNA in genital specimens from infants
}

\author{
S Chen, J Slavin, C K Fairley, S N Tabrizi, A J Borg, V Billson, S M Garland
}

\begin{abstract}
Objective-To identify the prevalence of HPV DNA using the polymerase chain reaction (PCR) in neonatal foreskin and cervical specimens obtained at necropsy. Materials-Foreskin and cervical specimens were obtained from consecutive neonates who had autopsies performed at The Royal Women's Hospital, Melbourne, from June 1991 to February 1992. Specimens were analysed for HPV DNA using the polymerase chain reaction and the $L 1$ consensus primers and generic probes.
\end{abstract}

Results-Specimens were obtained from 98 neonates, 52 male and 46 female. The mean gestational age of the neonates was 29 weeks (range 20-42). Eighty neonates died in utero, three during labour and 15 following delivery. Ninety four were delivered vaginally whilst four were delivered by caesarean section. Samples were collected a mean of 20 hours (range 2-48) from the time of delivery. In 30 cases there was evidence of autolytic change while in the remaining cases, the histology was well preserved. No evidence of HPV DNA was found in any of the samples using the L1 general primers (95\% confidence interval 0-3.6\%). Recent cervical cytology was available on 70 of the infant's mothers. Six had cytological evidence of HPV infection while the remainder were normal.

Conclusions-HPV DNA is uncommonly detected (by PCR) in foreskin and cervical specimens obtained from neonates.

(Genitourin Med 1993;69:270-272)

\section{Introduction}

Vertical transmission of human papillomavirus (HPV) infection from mother to baby can occur. Evidence includes the well established association between a maternal history of genital warts and the development of laryngeal papillomas in children less than 2 years of age, together with two case reports of infants who had genital warts present at the time of delivery. ${ }^{1-3}$

The efficiency of vertical transmission is, however, less well established. Genital warts in neonates have rarely been reported and are very uncommon in children in the first year of life. ${ }^{23}$ Laryngeal papillomas are estimated to be several hundred to 1000 fold less common than maternal genital infection, at the time of delivery. ${ }^{4}$ These observations would suggest that the efficiency of vertical transmission from mother to neonates who develop clinical disease is poor.

Several studies have addressed vertical transmission by assessing the presence of HPV DNA in neonates, rather than evaluating the clinical disease associated with this infection. ${ }^{5-7}$ Using DNA hybridisation techniques HPV DNA can be detected whether or not the infection is clinically apparent. Using Southern or dot blot hybridisation, three studies have detected HPV DNA in oral or genital samples from babies at or shortly after birth. ${ }^{5-7}$ Two studies also obtained samples from the infants' mothers and reported that HPV DNA can be detected in $0-79 \%$ of neonates born to mothers who were themselves positive for HPV DNA. ${ }^{56}$ These studies suggest that the babies become exposed at or before birth to sufficient virus for HPV DNA to be detected by these techniques (that is at least 10000 copies of viral DNA). It is not yet established whether this represents true infection of the infants epithelium or transient colonisation of the virus.

Recently, a much more sensitive technique, the polymerase chain reaction (PCR) has become available for the detection of DNA. This technique is theoretically able to detect as little as a single copy of HPV DNA. Using this technique and the $\mathrm{Ll}$ consensus primer, about $20-30 \%$ of sexually active young women have evidence of HPV DNA on cervical samples. ${ }^{8}$ Others have used PCR with type specific primers (HPV 16) and reported the presence HPV DNA in maternal peripheral blood lymphocytes (9 of 52) and cord blood (7 of 52). ${ }^{9}$ These studies suggest that exposure of infants to this virus during pregnancy or during vaginal delivery may be common. The aim of this study was to identify the prevalence of HPV DNA using PCR in genital biopsies from neonates. Foreskins, and cervical specimens were obtained at autopsy from neonates who had died in utero, during labour or shortly after birth.

\section{Methods}

Specimens were collected over a 6 month period on consecutive neonates who underwent routine autopsy at The Royal Women's Hospital from July 1991 to February 1992. Of the 98 cases, 58 were from The Royal Women's Hospital which offers a perinatal autopsy service, while the remainder were referred from other hospitals. Twenty six \\ 31 March 1993
}


were from community obstetric hospitals, 11 from private hospitals and three from country hospitals. In each case the foreskin or cervical specimen was taken as the first procedure. Cervical specimens were taken from an abdominal approach without contact with the perineal skin.

Written informed consent was obtained for an autopsy from the parents and the research was carried out in line with the National Health and Medical Research Council of Australia, guide-lines for human experimentation. These guide-lines are used by all Australian Hospital Ethics Committees.

Specimen collection: Specimens were immediately placed in HPV-transport medium (10 mM Tris- $\mathrm{HCl}, 50 \mathrm{mM}$ EDTA, $150 \mathrm{mM}$ $\mathrm{NaCl}, 0 \cdot 1 \% \mathrm{NaN}_{3}, \mathrm{pH} 7 \cdot 5$ ) and snap frozen in liquid nitrogen. They were stored at $-70^{\circ} \mathrm{C}$ until the DNA was extracted.

DNA extraction: Specimens were minced using a sterile scalpel and resuspended in $0.5 \mathrm{ml}$ of tissue-lysis-buffer $(20 \mathrm{mM}$ Tris$\mathrm{HCl}, 2 \mathrm{mM}$ EDTA, 1\% SDS, pH 8.0) for every $0.1 \mathrm{~g}$ of tissue. DNA was digested with proteinase $\mathrm{K}$ and RNAase, followed by phenol-chloroform extraction and ethanol precipitation according to standard procedure. ${ }^{10}$

To avoid contamination, the sample preparation was done in a class II biohazard hood in a separate room from that for analysis of PCR products. In addition, specimens from normal placentas were interposed between every five specimens throughout the sample handling, DNA extraction, and subsequent polymerase chain reaction.

PCR: One $\mu \mathrm{g}$ of DNA as determined by a spectrophotometer was amplified according to the method of Ting and Manos ${ }^{11}$ using consensus L1 primers (MY09-MY11). In addition, a 260 base pair segment of $\beta$-globin was amplified as an internal control using the primer set (GH20-PC04). This was included to ensure the presence of adequate amplifiable DNA. PCR products were probed using L1 generic probes (MY18, MY46, MY57 and WD147) under the conditions described by Resnick, et al. ${ }^{12}$

Positive controls were DNA from $\mathrm{SiHa}$ cell lines (1-2 copies of HPV DNA type 16/cell). Negative controls were interposed placental DNA and reaction mixtures without DNA.

\section{Results}

Specimens were obtained from 98 neonates; fifty two male and 46 female. The mean gestational age of the neonates was 29 weeks (range 20-42). Samples were collected a mean of 20 hours (range 2-48 hours) from the time of delivery. Eighty neonates died in utero, three during labour and 15 following delivery. Ninety four were delivered vaginally and four by caesarean section. In 30 cases there was evidence of autolytic change, while in the remaining cases the histology was well preserved.
No evidence of HPV DNA was found in any of the samples using the $\mathrm{L} 1$ consensus primers (95\% confidence interval $0-3 \cdot 6 \%$ ). All samples generated a strong $260 \mathrm{bp}$ band on the ethidium bromide stained agarose gel, corresponding to beta-globin. The sensitivity of the test was 10-20 copies of HPV DNA (10 Si Ha cells).

Recent cervical cytology was available on 70 of the mothers. Six had cytological evidence of HPV infection, while the remainder were normal.

\section{Discussion}

The results of this present study suggest that there is a low prevalence of HPV DNA (using PCR) in genital specimens obtained shortly after birth. There are no other published studies using PCR to assess HPV infection in similar samples although other hybridisation techniques have been used. The results of studies using Southern blot and dot blot hybridisation, vary widely with HPV DNA detected in $0 \%$ to $33 \%$ of babies. ${ }^{5-7}$ There are a number of possible reasons for the observed differences in the published studies. These include: the time at which the sample was taken relative to birth, the prevalence in the maternal population and the type of specimen obtained.

The timing of the sample in relationship to birth may explain the differences between the various studies. This would be particularly so, if a positive result was due to transient colonisation resulting from contamination from the mother's vaginal epithelium and secretions, at the time of birth. Should this have occurred, one may expect a decreasing prevalence of HPV in the infants, the longer after birth the specimens were collected. This decrease would not be expected if a positive result represented true infection of the infant's epithelium with active viral shedding. One study obtained samples at the time of birth and showed that of babies born to infected mothers, $79 \%$ had detectable HPV DNA from nasopharyngeal aspirates. ${ }^{5}$ In another study, samples were collected a mean of 36 hours but not less than 24 hours after delivery. Only one of 11 nasopharyngeal swabs was positive when collected from babies whose mothers were also positive. ${ }^{6}$ Our samples were collected a mean of 20 hours after delivery and the results are more in keeping with the second study, even though no maternal samples were analysed. The results of these studies support transient colonisation rather than true infection with a decreasing prevalence of HPV reported the later the specimens were collected.

Another explanation for the differences in the four studies may be the type of specimen which was collected (table). This is because the different sampling techniques, (nasopharyngeal aspirates, oral pharyngeal swabs, vulval swabs, foreskin biopsies and cervical biopsies), collect cells from areas with a differing exposure to the external environment. If we assume that a positive result represents 
Studies assessing HPV DNA in neonates

\begin{tabular}{|c|c|c|c|c|c|}
\hline Reference & Type of sample (number) & $\begin{array}{l}\text { Infants, Number } \\
\text { positive (\%) }\end{array}$ & Time of sample & Technique & $\begin{array}{l}\text { Motherst } \\
\text { Number (\%) }\end{array}$ \\
\hline 5 Sedlacek & $\begin{array}{l}\text { Nasopharyngeal aspirate }(n=45) \\
\text { Amniotic fluid }{ }^{\star}(n=13)\end{array}$ & $\begin{array}{r}15(33 \%) \\
2(15 \%)\end{array}$ & $\begin{array}{l}\text { At birth } \\
\text { During labour }\end{array}$ & $\begin{array}{l}\text { Southern blot } \\
\text { Southern blot }\end{array}$ & $\begin{array}{l}25 \text { of } 45(56 \%) \\
10 \text { of } 13(77 \%)\end{array}$ \\
\hline 6 Smith & $\begin{array}{l}\text { Oral-pharyngeal swab }(n=72) \\
\text { Vulval swabs }(n=41)\end{array}$ & $\begin{array}{l}2(3 \%) \\
0\end{array}$ & $\begin{array}{l}24-72 \text { hrs after birth (mean } 36 \mathrm{hrs} \text { ) } \\
\text { As above }\end{array}$ & $\begin{array}{l}\text { ViraPap/ViraType } \\
\text { ViraPap/ViraType } \\
\text { ViraPap/ViraType }\end{array}$ & 13 of $72(18 \%)$ \\
\hline $\begin{array}{l}7 \text { Roman } \\
\text { Chen }\end{array}$ & $\begin{array}{l}\text { Foreskin biopsies }(n=70) \\
\text { Foreskin biopsies }(n=52) \\
\text { Cervical biopsies }(n=46)\end{array}$ & $\begin{array}{l}3(4 \%) \\
0 \\
0\end{array}$ & $\begin{array}{l}\text { Not specified } \\
2-48 \text { hours (mean } 20 \text { hours) }\end{array}$ & $\begin{array}{l}\text { Dot blot } \\
\text { PCR (L1 primer) }\end{array}$ & $\begin{array}{l}\text { Not tested } \\
\text { Not tested }\end{array}$ \\
\hline
\end{tabular}

*Amniotic fluid collected vaginally.

tCervical scrape.

transient colonisation (from the mothers vaginal secretions) and not established infection in the infant's epithelium, then the differences in these specimens may well be important. Nasopharyngeal aspirates collect surface cells from a wide area exposed to vaginal secretions (swallowing at and before birth). Foreskin samples and vulval swabs obtain cells from a smaller area while cervical specimens are obtained from an anatomically protected area. Thus one would expect nasopharyngeal aspirates to have the greatest chance of detecting HPV DNA, while cervical samples the least. There are few published data and the information is too diverse to make a definite conclusion but the results to date suggest this may be the case (table). Further studies comparing different sites in the same infants will be necessary to answer this question.

To draw conclusions about HPV transmission to infants, it is necessary to know the HPV status of the mother. Two studies obtained samples from mothers and enabled correlation between these and the corresponding infants samples (see above for details). In our study no samples were taken from the mothers for HPV analysis, so it is not possible to determine how many of the mothers were positive for HPV DNA. However, it has been established from large studies in the USA that the prevalence of HPV DNA using the more sensitive PCR method and the L1 general primers is about $20-30 \%$ in sexually active young women with normal cervical smears, and higher in those with abnormal smears. ${ }^{8}$ Six of the 70 mothers in whom results were available had a recent cervical smear showing cytological evidence of HPV infection, suggesting these women were not from a group at low risk of HPV infection. Nevertheless, the lack of specimens from the mothers weakens the conclusions, because the exact number of mothers who were HPV DNA positive is not known.

Specimens were obtained from neonates after death in our study. In 30 neonates some degree of autolysis was present histologically and it is possible that this made it more difficult to detect HPV DNA in the samples.

This paper suggests HPV DNA is rarely identified from cervical or foreskin specimens of babies born to mothers from the general community. This differs from some other published papers. We believe that these differences are because the identification of HPV DNA is likely to represent transient colonisation from vaginal secretions and not established infection. Thus its detection will be influenced by the type of specimen collected (for example, the cervix is protected anatomically), or by the timing of the sample in relation to birth (decreasing detection with delayed sampling). It remains to be determined how frequently true infection results from transient colonisation and in particular if it is responsible for disease or infection in adults. To determine this prospective studies of infants from the time of birth will be needed. In view of the underlying prevalence of latent HPV infection (20-30\%), the answer to this question will be relevant to many women and their infants.

The authors thank The Royal Women's Hospital Research and Education Fund for their financial support and the Victorian Health Promotion Foundation who had previously supplied support for the PCR machine. Dr Fairley is in receipt of a salary from the National Health and Medical Research Council.

1 Quick CA, Kryzyzek RA, Watts SL, et al. Relationship between condylomata and laryngeal papillomata. Ann Otol 1980;89:467-71.

2 Rogo KO, Nyansera PN. Congenital condylomata acuminata with meconuim staining of amniotic fluid and fetal hydrocephalus: case report. East African Medical fournal. 1989;66:411-3.

3 Tang C, Shermeta DW, Wood C. Congenital condylomata acuminata. Am $\mathcal{F}$ Obstet Gynecol. 1978;131:912-3.

4 Kashima H, Shah K. Recurrent Respirator Papillomatosis. Clinical overview and management principles. Obstetrics and Gymecology Clinics of North America. 1987;14:581-8.

5 Sedlacek TV, Lindheim S, Eder BA, et al. Mechanism for human papillomavirus transmission at birth. $A m$ human papillomavirus transmiss

6 Smith EM, Johnson SR, Cripe TP, Pignatari S, Turek L. Perinatal vertical transmission of human papillomavirus and subsequent development of respiratory tract papillomatosis. Ann Otol Rhinol Laryngol 1991;100:479-83.

7 Roman A, Fife K. Human papillomavirus DNA associated with foreskins of normal newborns. $\mathcal{F}$ Infect Dis 1986;153:855-61.

8 Schiffman MH. Recent progress in defining the epidemiology of human papillomavirus infection and cervical neoplasia. $\mathcal{F}$ Nat Cancer Int. 1992;84:394-8.

9 Tseng C, Lin C, Wang R, et al Possible transplacental transmission of human papillomaviruses. Am 7 Obstet Gransmission of human

10 Sambrook J, Fritsch EF, Maniatis T. Molecular cloning: laboratory manual. 2nd ed. Cold Spring Harbour, NY: Cold Spring Harbor Laboratory Press. 1989.

11 Ting Y, Manos MM. Detection and typing of genital human papillomavirus. In: Innis MA, Gelfand DH, Sninsky JJ. White TJ, eds. PCR protocols. San Diego: Academic press. 1990;356-67.

12 Resnick RM, Cornelissen MT, Wright DK, et al. Detection and typing of human papillomavirus in archival cervical cancer specimens by DNA amplification with concesus primers. $\mathcal{f}$ Natl Cancer Inst 1990;82:1477-84. 